\title{
Optimization of AB-mix Fertilizer on Varieties of Hydroponic Lettuce (Lactuca sativa $\mathrm{L}$.)
}

\author{
Rosnina*1, Sarah Mauliza1 $^{1}$ \\ ${ }^{1}$ Department of Agroecotechnology, Faculty of Agriculture, Universitas Malikussaleh \\ Jl. Cot Tengku Nie Reuleut, Muara Batu, Aceh Utara 24355 \\ *Corresponding author: rosnina@unimal.ac.id
}

\section{ARTICLE HISTORY}

Received : 23 August 2020

Revised : 12 September 2020

Accepted : 25 September 2020

\section{KEYWORDS}

Lettuce ;

AB-mix Fertilizer;

Hydroponic;

Plant Nutrition;

\begin{abstract}
Lettuce (Lactuca sativa L.) is a popular leafy vegetable. Most of its varieties are eaten fresh and commonly served as a garnish in fried rice or complementary vegetables in some fast food meals such as burgers and green salads. Nowadays, most lettuce varieties are grown hydroponically, replacing the soil and feeding all nutrients through the water. A hydroponic system is also considered a solution to overcome the shortage of arable lands and good-quality water. This research aims to evaluate the lettuce response towards the application of AB-mix fertilizer in the hydroponic system. This research was designed using Factorial Randomized Block Design (RBD) with two factors ( $A B$ mix concentrations and lettuce varieties) and three replications. The results revealed between $A B$-mix concentrations and lettuce varieties, where the application of AB-mix increased the number of leaves. AB-mix's application gave an effect to all variables observed: plant height, leaf width, leaf number, and leaf chlorophyll but insignificant to root length.
\end{abstract}

This is an open-access article under the CC-BY-SA license.

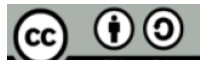

\section{INTRODUCTION}

Lettuce (Lactuca sativa L.) is a leafy vegetable belonging to the Asteraceae family, mostly eaten fresh. In recent years, lettuce demand has increased, as the demand from retails, hotels, and restaurants for fresh fruits and salads is growing due to health trends (Cahyono, 2005). Lettuce provides high fiber, provitamin A (carotenoid), potassium, and calcium (Supriati \& Herliana, 2014). The scarce arable land now has been an obstacle in growing good-quality Lettuce. Therefore, many farmers are expecting to grow Lettuce through biotechnology applications such as hydroponic systems to produce Lettuce intensively.

Hydroponic technology is innovation and alternative to grow a plant using substrate/soil-less technology (Siregar, et al., 2015). Rock wool is one of the most common media used in hydroponics. Rockwool is sterile, porous, and has good aeration to support plants' needs to have sufficient nutrition for their growth and development (Perwitasari, et al., 2012). Vidiyanto, et al. (2013) explained that the hydroponic system also helped minimize the plants' experiencing low quality of soil, water, and nutrition, mostly when plants grew in suboptimal lands.

In this hydroponic system, nutrition was fed through the media. AB-mix is a common fertilizer used to nourish the plants. This fertilizer contains macronutrients $\mathrm{C}, \mathrm{H}, \mathrm{O}$, $\mathrm{N}, \mathrm{P}, \mathrm{K}, \mathrm{Ca}, \mathrm{Mg}$ and $\mathrm{S}$, and micronutrients $\mathrm{Mn}, \mathrm{Cu}, \mathrm{Fe}, \mathrm{Mo}$, $\mathrm{Zn}$, and $\mathrm{B}$ in adequate amounts needed by plants their - growth (Hidayanti \& Kartika, 2019). Not only those nutrients, the use of substrates also play an important role in the success of hydroponics. It is necessary to add some nutrients to ensure that the plants grow and develop well (Silvina \& Syafrinal, 2008).

This research aimed to evaluate the growth and development of Lettuce due to the application of AB-mix fertilizer in different concentrations.

\section{MATERIALS AND METHODS}

The research was conducted in Agro Wisata Bina Hijau, Meuria Paloh, Lhokseumawe and Laboratory of Agroecotechnology, Faculty of Agriculture, Universitas Malikussaleh from January to February 2019.

\section{$2.1 \quad$ Research Methods}

Seed Sowing. Seed sowing was done using Rockwool. The seeds were placed in the rockwool, one seed per Rockwool cube, which was $2-3 \mathrm{~cm}$ in the distance, and then the Rockwool was placed in trays.

Lettuce Transplanting. After ten days, the plants with 34 leaves were replaced into net pots provided with flannel fabric. This fabric will absorb the nutrients ABmix, which is prepared in 2 and $5 \mathrm{ml}$ of concentrations. The nutrients provision was carried out three days in an interval using a TDS (Total Dissolved Solids) meter. 
Plant Maintenance. This activity includes replanting, renewing nutrients, fertilizing, and protecting the plants from pest and disease attacks. Harvesting can be done five weeks after planting when the plants reached the desired size before maturity (no flowers appeared).

\section{$2.2 \quad$ Variables Observed}

Variables observed were leaf number, leaf width $\left(\mathrm{cm}^{2}\right)$, plant height $(\mathrm{cm})$ at 14, 21, and 28 after planting. Leaf width was measured from leafapex to the petiole's junction using Leaf Area Meter (LAM). The total leaf area was measured at 14 days after planting. A chlorophyll meter was used to calculate the number of chlorophyll present in plants. Plant fresh weight (g) was calculated by weighing all parts of the plant, including the roots. Root length $(\mathrm{cm})$ was measured using a ruler, from its base to tip.

\begin{tabular}{|c|c|c|c|c|c|c|c|}
\hline \multirow{2}{*}{ Factor } & \multicolumn{7}{|c|}{ Plant height $(\mathrm{cm})$} \\
\hline & 5 DAP & 10 DAP & 15 DAP & 20 DAP & 25 DAP & 30 DAP & 35 DAP \\
\hline \multicolumn{8}{|c|}{ AB- mix concentrations } \\
\hline C1 (2 ml/L water) & $2.61 \mathrm{a}$ & $2.91 \mathrm{a}$ & $3.13 \mathrm{~b}$ & $4.83 \mathrm{c}$ & $6.81 \mathrm{~b}$ & $7.44 \mathrm{c}$ & $9.33 \mathrm{c}$ \\
\hline C2 (5 ml/L water) & $2.33 \mathrm{a}$ & $2.29 \mathrm{a}$ & $3.89 \mathrm{a}$ & $6.03 \mathrm{~b}$ & $8.61 \mathrm{a}$ & $9.20 \mathrm{~b}$ & $11.03 \mathrm{~b}$ \\
\hline C3 (8 ml/L water) & $2.64 \mathrm{a}$ & $3.30 \mathrm{a}$ & $4.35 \mathrm{a}$ & $6.81 \mathrm{a}$ & $9.35 \mathrm{a}$ & $10.41 \mathrm{a}$ & $12.92 \mathrm{a}$ \\
\hline \multicolumn{8}{|c|}{ Varieties (V) } \\
\hline V1 (Selada Merah) & $1.81 \mathrm{c}$ & $2.26 \mathrm{c}$ & $3.14 \mathrm{~b}$ & $4.91 \mathrm{c}$ & $6.92 \mathrm{c}$ & $7.50 \mathrm{~b}$ & $9.21 \mathrm{~b}$ \\
\hline V2 (Cristine) & $3.17 \mathrm{a}$ & $3.81 \mathrm{a}$ & $4.59 \mathrm{a}$ & $6.97 \mathrm{a}$ & $9.50 \mathrm{a}$ & $9.89 \mathrm{a}$ & $12.25 \mathrm{a}$ \\
\hline V3 (Lettuce) & $2.61 \mathrm{~b}$ & $3.12 \mathrm{~b}$ & $3.65 \mathrm{~b}$ & $5.80 \mathrm{~b}$ & $8.35 \mathrm{~b}$ & $9.66 \mathrm{a}$ & $11.83 \mathrm{a}$ \\
\hline
\end{tabular}

\section{RESULTS AND DISCUSSIONS}

\subsection{Results}

\subsubsection{Plant Height}

The results exhibited that different $\mathrm{AB}$-mix fertilizer concentrations applied to plants did not show plants' effect until ten days after planting (DAP). The fertilizer significantly affected the plants at 15-35 DAP. The results were given in Table 1.

Mean values followed by the same letters in the same columns did not differ as determined by DMRT at 5\% probability level

From the results in the table above, it can be said that different concentrations of $\mathrm{AB}$-mix in several varieties of Lettuce did not have any effect on plants at 5-10 DAP. The effects on the plants were observed significantly at 15-35 DAP. Concentration $8 \mathrm{ml} / \mathrm{L}$ water was found to be the best concentration, and the best height was demonstrated by lettuce variety Cristine.

\subsubsection{Leaf Width}

The results of ANOVA described that there were no significant effects of AB-mix application on leaf width. However, the application of AB-mix alone (without considering its varieties) has significantly improved the leaf width at 5-35 DAP.

\begin{tabular}{|c|c|c|c|c|c|c|c|}
\hline \multirow{2}{*}{ Factor } & \multicolumn{7}{|c|}{ Leaf Width $(\mathrm{cm})$} \\
\hline & $5 \mathrm{WAP}$ & $10 \mathrm{WAP}$ & 15 WAP & $20 \mathrm{WAP}$ & 25 WAP & $30 \mathrm{WAP}$ & $35 \mathrm{WAP}$ \\
\hline \multicolumn{8}{|c|}{ AB- mix concentrations } \\
\hline C1 (2 ml/L water) & $1.11 \mathrm{a}$ & $1.04 \mathrm{~b}$ & $1.88 \mathrm{~b}$ & $3.24 \mathrm{c}$ & $4.63 \mathrm{c}$ & $5.24 \mathrm{c}$ & $6.55 \mathrm{c}$ \\
\hline C2 (5 ml/L water) & $0.90 \mathrm{~b}$ & $1.33 \mathrm{a}$ & $2.68 \mathrm{a}$ & $4.48 \mathrm{~b}$ & $6.34 \mathrm{~b}$ & $7.01 \mathrm{~b}$ & $8.11 \mathrm{~b}$ \\
\hline C3 (8 ml/L water) & $0.87 \mathrm{~b}$ & $1.46 \mathrm{a}$ & $2.92 \mathrm{a}$ & $5.46 \mathrm{a}$ & $7.53 \mathrm{a}$ & $8.31 \mathrm{a}$ & $9.18 \mathrm{a}$ \\
\hline \multicolumn{8}{|c|}{ Varieties (V) } \\
\hline V1 (Selada Merah) & $1.00 \mathrm{a}$ & $1.41 \mathrm{a}$ & $2.70 \mathrm{a}$ & $4.32 \mathrm{ab}$ & $5.77 \mathrm{a}$ & $6.38 \mathrm{a}$ & $7.20 \mathrm{~b}$ \\
\hline V2 (Cristine) & $0.99 \mathrm{a}$ & $1.43 \mathrm{a}$ & $2.69 \mathrm{a}$ & $4.91 \mathrm{a}$ & $6.60 \mathrm{a}$ & $7.04 \mathrm{a}$ & $7.80 \mathrm{ab}$ \\
\hline V3 (Lettuce) & $0.89 \mathrm{a}$ & $1.00 \mathrm{~b}$ & $2.10 \mathrm{~b}$ & $3.95 \mathrm{~b}$ & $6.14 \mathrm{a}$ & $7.14 \mathrm{a}$ & $8.84 \mathrm{a}$ \\
\hline
\end{tabular}

Mean values followed by the same letters in the same columns did not differ as determined by DMRT at 5\% probability level

Results in Table 2 illustrated that the application of 5-8 $\mathrm{ml} / \mathrm{L}$ water had increased the leaf width at 5-15 DAP and the width significantly improved at 20-35 DAP. For the varieties, the improvement was recorded at 10,15 , and 20 DAP. The highest leaf width was exhibited by applying 8 $\mathrm{ml} / \mathrm{L}$ water $\mathrm{AB}-\mathrm{mix}(9.18 \mathrm{~cm})$, and for the lettuce variety, variety Lettuce demonstrated the widest leaf $(8.84 \mathrm{~cm})$.

\subsubsection{Leaf Number}

The results of ANOVA showed a significant interaction between the application of AB-mix and lettuce varieties on lettuce growth at 10 and 15 DAP. The results were presented in Table 3. 
Table 3. Interaction between AB-mix and lettuce varieties on leaf number

\begin{tabular}{lcc}
\hline \multirow{2}{*}{ Interaction between AB-mix concentrations and lettuce varieties } & \multicolumn{2}{c}{ Leaf Number } \\
\cline { 2 - 3 } C1V1 (AB mix $2 \mathrm{ml} / \mathrm{L}$ water + variety selada merah) & 10 DAP & $4.55 \mathrm{~cd}$ \\
C1V2 (AB mix $2 \mathrm{ml} / \mathrm{L}$ water + variety Cristine) & $5.55 \mathrm{ab}$ & $5.89 \mathrm{a}$ \\
C1V3 (AB mix $2 \mathrm{ml} / \mathrm{L}$ water + variety Lettuce) & $2.22 \mathrm{~d}$ & $3.11 \mathrm{e}$ \\
C2V1 (AB mix $5 \mathrm{ml} / \mathrm{L}$ water + variety Selada Merah) & $4.33 \mathrm{ab}$ & $5.00 \mathrm{bcd}$ \\
C2V2 ((AB mix $5 \mathrm{ml} / \mathrm{L}$ water + variety Cristine) & $4.22 \mathrm{~b}$ & $5.44 \mathrm{ba}$ \\
C2V3 (AB mix $5 \mathrm{ml} / \mathrm{L}$ water + variety Lettuce) & $3.00 \mathrm{~cd}$ & $4.22 \mathrm{~d}$ \\
C3V1 (AB mix $8 \mathrm{ml} / \mathrm{L}$ water + variety Selada Merah) & $2.89 \mathrm{~cd}$. & $5.33 \mathrm{abc}$ \\
C3V2 (AB mix $8 \mathrm{ml} / \mathrm{L}$ water + variety Cristine) & $3.33 \mathrm{c}$ & $5.55 \mathrm{ab}$ \\
C3V3 (AB mix $8 \mathrm{ml} / \mathrm{L}$ water + variety Lettuce) & $3.00 \mathrm{~cd}$ & $4.55 \mathrm{~cd}$ \\
\hline Mean values followed by the same letters in the same columns did not differ as determined by DMRT at 5\% probability level
\end{tabular}

Table 3 presented the interaction between AB-mix concentrations and lettuce varieties. It showed that the interaction significantly improved the leaf number. The highest leaf number was found in interaction H1V2 (AB mix $2 \mathrm{ml} / \mathrm{L}$ water + variety Cristine), which reached up to 5.89 .

\subsubsection{Leaf Chlorophyll Content}

The ANOVA results in Table 4 described no interaction between $\mathrm{AB}$ mix concentrations and lettuce varieties in observation at 35 DAP. However, the application of these two factors alone significantly increased the chlorophyll content.

\begin{tabular}{lc}
\hline $\begin{array}{c}\text { Table 4. Influence of concentrations of AB-mix and lettuce } \\
\text { varieties on leaf chlorophyll content }\end{array}$ \\
\hline \multicolumn{1}{c}{ Factor } & $\begin{array}{c}\text { Chlorophyll content } \\
\text { (35 DAP) }\end{array}$ \\
\hline AB-mix concentrations (C) & $13.28 \mathrm{~b}$ \\
C1 (2 ml/L water) & $14.01 \mathrm{~b}$ \\
C2 (5 ml/L water) & $18.94 \mathrm{a}$ \\
C3 (8 ml/L water) & $18.16 \mathrm{a}$ \\
Varieties (V) & $13.20 \mathrm{~b}$ \\
V1 (Selada Merah) & $14.87 \mathrm{~b}$ \\
V2 (Cristine) & V3 (Lettuce) \\
Mean values followed by the same letters in the same columns did not \\
differ as determined by DMRT at 5\% probability level
\end{tabular}

Table 4 has shown that the increase of AB-mix concentrations on several varieties of Lettuce had significant results in the formation of leaf chlorophyll content. The highest chlorophyll content was shown by applying $8 \mathrm{ml} / \mathrm{L}$ water of AB-mix (18.94 cci), and for lettuce varieties, it was exhibited by variety Selada Merah (18.16 cci).

\subsubsection{Root Length}

Results in Table 5 presented that the application of ABmix alone did not affect root length if compared to each concentration. However, significant root length was recorded on lettuce varieties.

\begin{tabular}{|c|c|}
\hline Factor & $\begin{array}{c}\text { Root Length }(\mathrm{cm}) \\
\text { (35 DAP) }\end{array}$ \\
\hline \multicolumn{2}{|c|}{ AB-mix concentrations $(C)$} \\
\hline C1 (2 ml/L water) & $35.09 \mathrm{a}$ \\
\hline C2 (5 ml/L water) & $36.27 \mathrm{a}$ \\
\hline $\mathrm{C} 3$ (8 ml/L water) & $31.90 \mathrm{a}$ \\
\hline \multicolumn{2}{|l|}{ Varieties (V) } \\
\hline V1 (Selada Merah) & $40.89 a$ \\
\hline V2 (Cristine) & $32.09 \mathrm{a}$ \\
\hline V3 (Lettuce) & $30.28 \mathrm{~b}$ \\
\hline
\end{tabular}

From the results above, the application of $5 \mathrm{ml} / \mathrm{L}$ water demonstrated the longest roots $(36.27 \mathrm{~cm})$, but it did not differ compared to other concentrations. For the lettuce varieties, Selada Merah variety has been observed to have the longest roots $(40.89 \mathrm{~cm})$

\subsubsection{Lettuce Fresh Weight}

The ANOVA results in Table 5 revealed insignificant results of fresh weight due to interaction of $A B-m i x$ concentrations and lettuce varieties. However, the single application of those two factors gave significant results at 35 DAP.

Table 6. Influence of concentrations of AB-mix and lettuce varieties on fresh plant weight

\begin{tabular}{lc}
\hline \multicolumn{1}{c}{ Factor } & $\begin{array}{c}\text { Chlorophyll content } \\
\text { (35 DAP) }\end{array}$ \\
\hline AB-mix concentrations (C) & \\
C1 (2 ml/L water) & $17.46 \mathrm{~b}$ \\
C2 (5 ml/L water) & $25.16 \mathrm{~b}$ \\
C3 (8 ml/L water) & $37.79 \mathrm{a}$ \\
\hline Varieties (V) & $21.25 \mathrm{a}$ \\
V1 (Selada Merah) & $28.93 \mathrm{a}$ \\
V2 (Cristine) & $30.24 \mathrm{a}$ \\
V3 (Lettuce) & \\
\hline Mean values followed by the same letters in the same columns did not \\
differ as determined by DMRT at 5\% probability level
\end{tabular}

The results presented in Table 6 exhibited that the single application of those two variables alone significantly increased the fresh lettuce weight. The 
highest weight was recorded at the plant applied with 8 $\mathrm{ml} / \mathrm{L}$ water AB-mix (37.79 g), and for the lettuce varieties, the highest variety observed was variety Lettuce $(30.24$ g).

\subsection{Discussions}

The significant interaction between AB-mix concentrations and lettuce varieties on leaf number was observed at 10 and 15 DAP. For the single application of the two variables, AB-mix concentrations significantly increased the plant height, leaf width, and leaf number at 5-35 DAP. Variable plant height is a variable determining the growth of Lettuce. The vegetative stage is where the plants are busy carrying out photosynthesis and accumulating resources for its development, starting from cell division, cell elongation, and the first step of cell differentiation. These three processes need carbohydrates produced from nitrogen, which provides the nutrients that energize protoplasms at growth tips, increasing plant height. The availability of carbohydrates in plants influenced the sufficiency of nutrients available for the plants (Harlina, 2003). High accumulation of photosynthate caused cell enlargement and differentiation, determined by leaf width, plant height, and stem diameter.

Plant height is mostly related to leaf number. The higher number of leaves, the higher the number of internodes, which determines the increase of plant height. Plant height is a variable used to measure and influence the environment towards a treatment applied (Sitompul \& Guritno, 1995). In this research, we have observed that the application of AB-mix alone has significantly increased the plant height at 15-35 DAP, and for the varieties alone, it has shown a significant improvement of plant height at 5-35 DAP.

An increase in plant height due to the application of 8 $\mathrm{ml} / \mathrm{L}$ water $\mathrm{AB}$-mix was considered as a good result, where this means that concentration was the best amount to be applied to lettuce plants to grow and develop well. The nutrients available enhance plant growth. From the experiments we have done, we can confirm that the increase of AB-mix concentrations can enhance plant growth. Suryani (2015) stated that low nutrient in plants had caused growth inhibition. Not only the nutrients, the growing media used to grow the plants also influence the plant growth. In this research, we used Rockwool as a growing media. This media has lightweight substrates, soft and microparticles that enable it to absorb water and nutrients well for lettuce plants' optimal growth.

Generally, the variety of Cristine grows well in this research. However, there were several differences between the variations in growth rate and production and its genetic characteristics. Good genetic characteristics play a significant role in plant growth and to produce good-quality yield. The high productivity of a plant is linked to its planting technique and agronomic performance. Like Darliah, et al. (2001), different environments will produce different genotypes of plants.
The factors affecting the genotype performance appeared in its phenotype, for example, its plant height.

The application of optimal nutrition to lettuce plants can enhance its leaf area. The results of this research showed that the application of AB-mix had improved lettuce leaf area. It was because this fertilizer has essential nutrients needed by the lettuce plants. Water, nutrients, and sunlight mostly influence the leaf width. Manullang, et al. (2020) agreed that AB-mix is an appropriate fertilizer applied to leafy plants such as Lettuce. Nugraha (2014) also informed that additional nutrients given to plants are macro and micronutrients required for the plants called fertilizer A and B. Harjadi, et al. (2010) added that these nutrients are important for the plant growth and development. Those nutrients applied in the hydroponic system play an important role in the plant metabolic system and its physiology. The changes in plant height occurred at the vegetative stage, wherein this stage, cell division is very active, attributed to an increase in the number and size of cells, increasing plant height. At this stage, plants essentially need nitrogen for the cell division process, especially for the leaf and stem growth (Gardner, et al., 1991; Furoidah \& Wahyuni, 2017).

The results of this research demonstrated no interaction between $\mathrm{AB}$-mix concentrations and lettuce varieties. The best application of $A B-m i x$ alone was exhibited by applying $8 \mathrm{ml} / \mathrm{L}$ water $(9.18 \mathrm{~cm})$. This result has proved that AB-mix fertilizer was good for hydroponic Lettuce due to this fertilizer being absorbed by the plants well. Furoidah \& Wahyuni (2017) explained that $\mathrm{AB}$ mix is a complete fertilizer that contains nutrients needed by plants for their growth and development. Leaf width affects the energy quantity absorbed from the sunlight. The wider leaf size enables plants to absorb more energy, which establishes sufficient energy to create more branches and leaves.

Sufficient nutrients produced a good yield. In this research, the best leaf width was $8.84 \mathrm{~cm}$, demonstrated by Lettuce's variety, the best result compared to the other two varieties. It happens due to each variety possessing different absorbing nutrients, especially the nutrients that are responsible for expanding the plant leaves. Variety Lettuce is known to have distinguished characteristics compared to other varieties. This intrinsic potency determines the ability of plants to grow and develop well where it has been planted.

Leaves are an important part of a plant. They are green in color due to its chlorophyll content. Leaves are responsible for absorbing energy from the sunlight for photosynthesis. The wider size of leaves allows more energy to be absorbed, increasing photosynthesis activity. An increase of photosynthesis rate contributed to equitable distribution of photosynthate to all plant parts. This research confirmed that there was an interaction between AB-mix concentrations and lettuce varieties at 10 and 15 DAP, which proved that this fertilizer had met the needs of plant leaves for its development. An adequate supply of nitrogen to leaves has widened the 
leaves and enhanced the chlorophyll content, exhibited abundant production of carbohydrates to support the plant growth in the vegetative stage. Leaf growth is linked to photosynthesis activity, which determines photosynthate availability in supporting plant growth.

For the leaf number, the results described that the highest number exhibited by the interaction $A B$ mix 2 $\mathrm{ml} / \mathrm{L}$ water and variety Cristine (H1V2) which reached up to 5.89 at 15 DAP, while the lowest possessed by interaction $\mathrm{AB}$ mix $2 \mathrm{ml} / \mathrm{L}$ water and variety Lettuce, which reached 3.11 at $15 \mathrm{DAP}$. The application of $5 \mathrm{ml} / \mathrm{L}$ water AB-mix only significant at 10 and 15 DAP and insignificant for interaction between those two factors between plant age at each observation. These insignificant results might happen due to the plants having optimally absorbed the leaf growth nutrients.

The vegetative stage in a plant is influenced by plant type and water and nutrients availability. However, the requirement for water and nutrients varies for each plant. This variation depends on plant type, growth phase, and environment where the plant is grown, affecting the plant development and the yield. Saroh, et al. (2017) investigated that the application of $\mathrm{AB}$ mix $5 \mathrm{ml} / \mathrm{L}$ water was the best concentration on lettuce plants with Rockwool media. Rockwool media is known to have the ability to absorb and to store more water to keep the plant moisturized and to have sufficient water for photosynthesis activity. The nutrients $\mathrm{N}, \mathrm{P}$, and $\mathrm{K}$ contain in $A B-m i x$ fertilizer have increased the lettuce leaf in this research.

The application of AB-mix less than $5 \mathrm{ml} / \mathrm{L}$ water showed improper growth of Lettuce due to nutrient deficiency. This statement is similar to Waskito (2016) research, which found that nitrogen deficiency has caused plants to have stunted growth, weak leaf growth inhibition, and chlorotic leaves. The development of plants varies between each variety, resulting in their various appearances. Therefore, in its vegetative stage, the maintenance needs to be optimally done to get an optimal yield with better quality, determined by its normal size, bright green color, and free from pest and disease attack.

Chlorophyll is an important component in plants, algae and photosynthetic bacteria. This component plays an important role in photosynthetic activity. Chlorophyll content measurement is an important variable in researches evaluating green plants. In this research, the highest chlorophyll content was demonstrated by applying $8 \mathrm{ml} / \mathrm{L}$ water AB-mix concentration (18.94), and for the lettuce varieties, the highest content was exhibited by Selada Merah variety (18.16). These results illustrated that the chlorophyll content was increased as the $\mathrm{AB}$ mix concentrations increased, resulting in better photosynthesis activity which produced higher photosynthate. These results also were in line with the finding of Suwardi \& Efendi (2009). They evaluated that the application of $\mathrm{N}$ has increased the chlorophyll. There was chlorophyll $a$, absorbing energy from longwavelength (red light, > $685 \mathrm{~nm}$ ), and also it acts as photosynthetic reaction center, and chlorophyll $b$, absorbing blue light (short wavelength) (Suminarti, 2010). Red Selada performed better than other varieties. Harjadi (1991) stated that each variety possesses different genotypes, which influenced its phenotypes and its adjustment in the environment.

Roots are important plant parts to absorb water, nutrients, minerals, and essential components needed by plants to grow and develop (Gardner, 1991). Root growth and its length contributed to the success in nutrient uptake. A plant with long roots can absorb more nutrients. This research has shown that there was no interaction between AB-mix concentrations and lettuce varieties at harvest time. Table 5 shows no significant result on root length at the application of $\mathrm{AB}$-mix alone (the longest was $36.27 \mathrm{~cm}$ ). The application of $5 \mathrm{ml} / \mathrm{L}$ water has demonstrated the longest root compared to other concentrations applied. It might be due to high oxygen for respiration has been allocated for root growth, resulting in the rapid growth of roots, where this rapid growth enabled plants to absorb more water and nutrients.

Morgan (2000) confirmed that plant roots use the dissolved oxygen contained in nutrients for aerobic respiration, which releases the energy for root growth. It proved that with more nutrients applied to the plants, it would produce shorter roots. However, this research investigated that the Selada Merah variety demonstrated the longest roots $(40.59 \mathrm{~cm})$.

The plant growth varied between varieties, where this difference is influenced by plant genetics and the environment. Plant roots require three important components, such as water, nutrients, and oxygen. In this research, the difference in variety is attributed to the difference in absorbing nutrients through its roots.

\section{CONCLUSIONS}

An increase of $A B$ mix concentration to $8 \mathrm{ml} / \mathrm{L}$ water has increased the yield of hydroponic Lettuce. $A B$ mix exhibited the best results on plant height, leaf width, leaf number, chlorophyll content, and root length, but it had no response on total fresh weight. There was an interaction between $\mathrm{AB}$-mix concentrations and lettuce varieties on lettuce leaves at 10 and 15 DAP.

\section{REFERENCES}

Cahyono, B. (2005). Teknik budidaya dan analisis usaha tani selada. Semarang: Aneka Ilmu.

Darliah, I. S., de Vrees, D. P., Handayati, W., Herawati, T., \& Sutater, T. (2001). Variabilitas genetik, heritabilitas, dan penampilan fenotipik 18 klon mawar di Cipanas. J. Hort, 11(3), 148-154.

Furoidah, N., \& Wahyuni, E. S. (2017). Peningkatan Hasil Sayuran Lokal Kabupaten Lumajang di Lahan Terbatas. Jurnal Agri-Tek, 17(2).

Gardner, F. P., Pearce, R. B., Mitchell, R. L., \& Susilo, H. (1991). Fisiologi tanaman budidaya. Penerbit Universitas Subiyanto.

Harjadi, M. M. S. S (1991). Pengantar Agronomi. Penerbit Gramedia. Jakarta.

Harjadi, S. S., Winarno, W. D., \& Ketty, S. (2010). Aspek-Aspek Penting Budidaya Tanaman Buah-Buahan. Dihimpun oleh GA Wattimena.

Hidayanti, L., \& Kartika, T. (2019). Pengaruh Nutrisi AB Mix Terhadap Pertumbuhan Tanaman Bayam Merah (Amaranthus tricolor L.) 
secara Hidroponik. Sainmatika: Jurnal Ilmiah Matematika dan Ilmu Pengetahuan Alam, 16(2), 166-175.

Manullang, I. F., Hasibuan, S., \& CH, R. M. (2020). Pengaruh Nutrisi Mix dan Media Tanam Berbeda Terhadap Pertumbuhan dan Produksi Tanaman Selada (Lactuca sativa) secara Hidroponik dengan Sistem Wick. Bernas, 15(1), 82-90.

Morgan, L. (2000). Are your plants suffocating. The importance of oxygen in hydroponics. The Growing Edge, 12(6), 50-54.

Nugraha, R. U. (2014). Sumber hara sebagai pengganti AB mix pada budidaya sayuran daun secara hidroponik. Departemen Agronomi dan Hortikultura: Institut Pertanian Bogor.

Perwitasari, B., Tripatmasari, M., \& Wasonowati, C. (2012). Pengaruh media tanam dan nutrisi terhadap pertumbuhan dan hasil tanaman pakcoy (Brassica juncea L.) dengan sistem hidroponik. Agrovigor: Jurnal Agroekoteknologi, 5(1), 14-25.

Saroh, M., Syawaluddin, S., \& Harahap, I. S. (2017). Pengaruh Jenis Media Tanam dan Larutan Ab Mix dengan Konsentrasi Berbeda pada Pertumbuhan dan Hasil Produksi Tanaman Selada (Lactuca sativa L) dengan Hidroponik Sistem Sumbu. Jurnal AGROHITA: Jurnal Agroteknologi Fakultas Pertanian Universitas Muhammadiyah Tapanuli Selatan, 1(1), 29-37.

Silvina, F, Syafrinal. (2008). Penggunaan berbagai media tanam dan konsentrasi pupuk organik cair pada pertumbuhan dan produksi mentimun jepang (Cucumis sativus) secara hidroponik. Jurnal
Sagu, 7(01).

Siregar, J. (2015). Pengujian beberapa nutrisi hidroponik pada selada (Lactuca sativa L.) dengan teknologi hidroponik sistem terapung (THST) termodifikasi.

Sitompul, S. M., \& Guritno, B. (1995). Analisis pertumbuhan tanaman.

Suminarti, N. E. (2010). Pengaruh pemupukan N dan K pada pertumbuhan dan hasil tanaman talas yang ditanam di lahan kering. Akta Agrosia, 13(1), 1-7.

Supriati, Y., \& Herlina, E. (15). Sayuran Organik dalam Pot. Jakarta: Penebar Swadaya, 148.

Suryani, R. (2015). Hidroponik budidaya tanaman tanpa tanah. Yogyakarta: Arcitra, 200.

Suwardi \& Efendi, E. (2009). Efisiensi Penggunaan Pupuk N pada Jagung Komposit Menggunakan Bagan Warna Daun. Prosiding Seminar Nasional Serealia 2009.

Vidianto, D. Z., Fatimah, S., \& Wasonowati, C. (2013). Penerapan panjang talang dan jarak tanam dengan sistem hidroponik NFT (nutrient film technique) pada tanaman kailan (Brassica oleraceae var. alboglabra). Agrovigor: Jurnal Agroekoteknologi, 6(2), 128-135.

Waskito, A. B. (2016). Formulasi Kompos Kirinyuh Azolla dengan Penambahan Pupuk P dalam Meningkatkan Pertumbuhan dan Produksi Tanaman Pare (Momordica charantia L.). Skripsi. Fakultas Pertanian Universitas Muhammadiyah Jember. 